\title{
CALL FOR PAPERS: THE FIRST 20 YEARS OF LAW AND HUMAN BEHAVIOR
}

Law and Human Behavior invites manuscript submissions for a special issue celebrating the 20th anniversary of the inception of the journal. We are interested in developing a special issue that reviews various areas within the field of law and psychology from an empirical and vonceptual perspective. We intend to publish articles that bring together programs or bodies of research that contribute to our understanding of a topic or area within law and psychology. One goal of the special issue is to represent the field broadly. To this end, we would especially welcome manuscripts that represent bodies of work that have not yet received adequate attention from psycholegal scholars. Manuscripts that discuss the contributions of the field to law or that analyze the discipline as a whole are welcomed as well. These latter papers should focus on the conceptual underpinnings of an area of psychology and law. Finally, international and cross-cultural perspectives will be considered.

The editor for this issue is James R. P. Ogloff of the Mental Health, Law, and Policy Institute at Simon Fraser University. Four copies of manuscripts should be sent to:

James R. P. Ogloff, J.D., P.D.

Department of Psychology

Simon Fraser University

Burnaby, British Columbia

Canada V5A IS6

E-mail: jogloff@arts.sfu.ca

To be considered for this special issue, manuscripts must be postmarked no later than November 1, 1997. 